\title{
Investor Protection Through Exchange Transaction Settlement Guarantee And Investor Protection Fund
}

\author{
Lastuti Abubakar \\ Economic Law Department Faculty of Law Universitas Padjadjaran, Indonesia \\ lastuti62abubakar@gmail.com \\ Tri Handayani \\ Economic Law Department Faculty of Law Universitas Padjadjaran, Indonesia \\ t212h@yahoo.com
}

\begin{abstract}
Certainty and investors legal protection is the key to the success of capital market as financing and investment alternatives. To fulfill the international standards, Indonesia capital market regulation regulates the status of Clearing and Underwriter Institutions organized by Indonesian Clearing and Guarantee Corporation (KPEI) and serves to guarantee transactions settlement in Exchange as well as managing the Guarantee Fund. Other investor protection organized by the Indonesia Securities Investor Protection Fund (SIPF) formed to protect the assets of investors who lost and manage the Investor Protection Fund. This study aims to examine the position of KPEI as guaranteeing institution for the settlement of Exchange transactions to prevent settlement failures that can have systemic impacts, including how to optimize the management of Guarantee Funds. In addition, it was also examined how Indonesia SIPF could manage the Investor Protection Fund optimally in order to provide maximum protection. The method used is normative juridical with descriptive analytical research specifications. Data analysis used is qualitative juridical. Based on the results, KPEI is financial market infrastructure to prevent failure of potentially systemic transactions. Therefore, KPEI can be included as systemic financial institution. Either management of the Guarantee Fund by KPEI or Investor Protection Fund management by SIPF can use the trust concept to be able to increase the Guarantee Fund and Investor Protection Fund so that the guarantee of Exchange transaction settlement and investor protection is more certain and optimal.
\end{abstract}

Keywords: Investor Protection, Central Counterparty \& Indonesia SIPF - Fund Management.

\section{INTRODUCTION}

Capital Market is part of the financial services industry which plays important role in national economic development. The contribution of the capital market to the economy reached 12\% in 2017, up 10\% from 2016 through state tax revenues of Rp.110 trillion. The trust of businesses men to attract public funds through public offerings shows graph that increases compared to 2017, which is 35 public offerings on September 18, 2018 compared to 38 public offerings in 2017. From the values obtained, on September 18, 2018 amounted to Rp.21,622, 95 billion, exceeding the value in 2017 of Rp. 9.598 .90 billion. ${ }^{1}$ In addition, the

\footnotetext{
${ }^{1}$ OJK, 2018: 18
} 
Indonesian Capital Market continues to develop securities instruments to attract investors, including developing Sharia securities, such as sukuk and Sharia mutual funds. At present sukuk is alternative for financing infrastructure in Indonesia. ${ }^{2}$ As alternative to financing the business world, the capital market facilitates companies to obtain financing through the securities issuance either debt instruments or equity instruments and the derivatives.

Unlike direct investment as long-term investment, investors in the capital market (portfolio investment) seek short-term profits through capital gains, namely the difference in selling prices and buying prices traded on the Indonesia Stock Exchange. Therefore, investment in the capital market has characteristics include: investors not as company owner, but company shareholders; investors do not aim to participate in managing the company to achieve company goals. Unlike direct investment, investment instruments in the capital market can be transferred at any time by investors through the mechanism of transactions in the Indonesia Stock Exchange.

As international standard capital market, the Indonesian Capital Market has opportunity to attract investment from both local and foreign investors, institutions and individuals. As part of global capital markets, the Indonesian capital market authorities following the developments and have implemented the principles that apply internationally, including the principles to be applied by institutions that belong to the financial market infrastructures that issued by the Bank for International Settlements (BIS) and the International Organization of Securities Commission (IOSCO). Principles for financial market infrastructures include Comprehensive guidelines or standards for financial market infrastructures role in facilitating payments, supporting processes and transaction settlement activity would also saving financial instruments ${ }^{3}$ Principles of financial market infrastructures are partly intended to apply at KPEI as the central counter party who will take over the rights and obligations of the parties in the settlement of exchange transactions.

Financial Market Infrastructure (FMI) is important aspect of the financial and economic system throughout the world, because if it is not managed properly, FMI can become financial crisis source. One of the FMIs in capital market activities is the Clearing Guarantee Institution (LKP) conducted by the Indonesian Clearing and Guarantee Corporation (KPEI), which is the party that organizes clearing and guarantee services for Exchange Transaction Settlement. The existence of LKP is regulated in Article 13 -17 of Law Number: 8 of 1995 concerning Capital Market (Capital Market Law). Based on Article 14 Paragraph (1) of the Capital Market Law, the LKP is established with the aim of providing regular, reasonable and efficient clearing and guarantee services for exchange settlement. Clearing activities are basically processes that are used to determine the obligations of Securities Exchange Members on the transactions carried out so that they know their respective rights and obligations. Whereas guarantees are to guarantee the transactions completion so that the parties to the transaction obtain their right. In addition to LKP, other FMIs that play role in the Capital Market are the Stock Exchange and the Depository and Settlement Institution (LPP). The Exchange, LKP and LPP act as the Self Regulatory Organization (SRO) which supports the creation of regular, fair and efficient trade to provide legal certainty and protection for investors. Based on the Explanation of Article 7 of the

\footnotetext{
${ }^{2}$ La stuti Abubakar \& Tri Handayani, Development of Regulations on Scripless Stock Guarantees as Objects of Transactions in the Capital Market, Justitia Legal Journal, Vol. 2, No. 1, 2018, http://journal.umsurabaya.ac.id/ index.php/Justitia/article/view/1715/1377 : 8

3 (BIS, IOSCO, 2012: 143)
} 
Capital Market Law, what is meant by regular, fair and efficient securities trading is trade held based on clear rule and implemented consistently. Thus, the price that occurs reflects the market mechanism based on demand and supply strength. Efficient securities trading is reflected in rapid settlement of transactions at relatively low costs. To realize this orderly, fair and efficient trading system, the Indonesia Stock Exchange effectively implemented scripless trading system in transactions on the Exchange since mid-2000. This Scripless trading system eliminates the physical forms of securities transacted and completes transactions through book entry. settlement), so that there is no physical transition effect. All securities traded on the Indonesia Stock Exchange converted into electronic data. All securities in the form of electronic data are then stored in the LPP held by the Indonesian Central Securities Depository (KSEI). The implementation of the scripless trading system is a form of strength of the Indonesian capital market in meeting international standards to create an orderly, fair and efficient market. ${ }^{4}$ Thus, it can be ascertained that regulations on the capital market have laid strong legal foundation for legal certainty and protection for investors.

However, in practice the legal problems are still found in the mechanism of transactions that have the potential to harm investors and can disrupt regular, fair and efficient trade. Practices in the capital market that are contrary to the objectives of the capital market and detrimental to investors include violation of the principle of information disclosure; guess the practice of market manipulation, pseudo trading, or insider trading; even illegal acts carried out by securities brokers (brokers) which results in losses for investors. In 2018, OJK is handling 46 cases in the capital market, which are related to information disclosure and stock transactions. $^{5}$

Violation of the information or transaction disclosure is very detrimental to investor because investors do not have access to companies whose securities are traded on the capital market. The only access for investors to make investment decisions is information about the Issuing Company, either through prospectus, company reports or material facts that must be published. Therefore, the principle of disclosure or transparency is main principle in the capital markets should be enforced. In addition to implementation of the transparency principle, transaction guarantees are important part of the transaction mechanism to ensure that investors obtain their right. Electronic-based trading systems make trade efficient, especially in terms of costs, but there are always weaknesses in technology side. Technical constraints in the use of information technology are common, such as technical constraints on the Enhancement e-CLEARS system at KPEI on July 7, 2017 which potentially causes mismatch of records of rights and obligations and ownership of securities and/ or funds arising from Exchange transactions. ${ }^{6}$ Relate to transactions guarantee, KPEI should anticipate acceleration of settlement from $\mathrm{T}+3$ to $\mathrm{T}+2$ in order to implement global best practice, which was launched on July 172018 and will be held on November 26, 2018. The implementation of $\mathrm{T}+2$ settlement gives benefits for the capital market industry, namely: 1) increasing harmonization between Exchanges globally so as to facilitate cross Exchange and/or country securities transactions; increase liquidity through the reinvestment acceleration from capital; improve operational efficiency; and reduce systemic risks that can occur in the Capital Market.

\footnotetext{
${ }^{4}$ La stuti Abubakar \& Tri Handayani, Development of Regulations on Scripless Stock Guarantees as Objects of Transactions in the Capital Market, Justitia Legal Journal, Vol. 2, No. 1, 2018, http://journal.umsurabaya.ac.id/ index.php/Justitia/article/view/1715/1377 : 190)

${ }^{5}$ Kontan .co.id, 2017

${ }^{6} \mathrm{KPEI} / \mathrm{KSEI}, 2017$
} 
Acceleration of the completion of this transaction is supported by advances in technology and the integration of information technology systems in the form of implementation of Straight Through Processing (STP), Single Investor Identification (SID), and Account Customer Funds (RDN) that enable faster turnaround of the completion of its current $\mathrm{T}+3$ (Transaction day plus 3 working days). The last trading day with $\mathrm{T}+3$ cycle is planned for November 23, 2018 and the first day of trading with $\mathrm{T}+2$ will be held on November 26, 2018, so that the first settlement with the $\mathrm{T}+2$ cycle falls on November $28,2018 .{ }^{7}$ The plan to implement the transaction settlement acceleration was announced in Press Release No. 061/BEI.KOM/072018, No. KPEI-001/SPE-PR/0718 and PR-003/KSEI/KPE/ 0718. The implementation of $\mathrm{T}+2$ is also feared to cause default. Therefore, KPEI and other SROs must anticipate this failure.

Beside that, KPEI does not guarantee all customer losses due to the Exchange transaction . KPEI only guarantees customer losses arising from failing to pay transactions. Customer losses due to errors or omissions of the security company are not the responsibility of KPEI. PT Sarijaya case, the securities company that caused customer losses due to embezzlement of funds by management in 2009 for example, was not KPEI's responsibility. These potential customer losses are concern to the authorities to carry out regulations related to guarantees for investors to maintain investor confidence in the Indonesian capital market. For the guarantee of transactions by KPEI, the Financial Services Authority (OJK) has issued OJK Regulations Number: 26/POJK.04/2014 concerning Guarantee of Exchange Transaction Settlement. Based on these POJK, KPEI obliged instantly and directly take over the responsibility of Clearing Member that fails to meet its obligations in the completion of the exchange transaction. In terms of legal aspects, KPEI replace the position of parties is debt renewal (novation). KPEI replaces the position of the parties and takes into account the rights and obligations of the parties (central counterparties). In carrying out its function as guarantor of Exchange transaction settlement, KPEI manages the guaranteed Fund which can be used to guarantee the Exchange transactions settlement. In addition to the Guarantee Fund, there are several financial sources in conducting the guarantee with the order of the use of financial resources originating from:

1) guarantee reserves, namely accumulation of funds originating from the provision of KPEI net profit in the amount of certain percentage in the form of cash or cash equivalents used to settle exchange transactions. Determination of these percentages is based on recommendations from the KPEI Credit Policy and Risk Management Committee and requests for approval through the General Meeting of Shareholders (GMS).

2) Banking Credit Facility; Bank credit facilities are obtained from one of the payment banks that have cooperated with KPEI in the case that "immediate" bailout funds can be used to guarantee the completion of the failure of a certain Clearing Member.

3) Guarantee Fund, is a collection of funds and / or securities administered and managed by KPEI which is used to guarantee Exchange Transaction Settlement.

4) Credit Network, which is financial source originating from other credit network members, which together bear the loss from the failure of certain clearing members.

${ }^{7}$ KPEI, 2018 
Based on the order of financial resources use, the credit network is used if all three funding sources have been used but are not sufficient. For each use of financial resources, it must be repaid by the Clearing Member who fails to complete the obligation to KPEI. KPEI repayments can be done by: 1) conducting the process of depositing funds and/or using financial resources for clearing members who fail to complete the Exchange transactions under KPEI's control no later than 2 trading days after the use of financial resources; in the failed clearing Member Guarantee account no later than 10 Exchange days after the use of financial resources; 3) requests for revocation of the Clearing Member's Securities Exchange membership which fails to be followed by the sale of the Stock Exchange shares and / or the sale of the failed Clearing Member's shares slow 60 Exchange days after the use of financial resources; 4) carry out the process of submitting bankruptcy application for failed clearing Member to OJK no later than 90 Exchange days after the use of financial resources followed by liquidation and / or sale of assets of the Clearing Member. Furthermore, after the money for payment of financial resources has been collected, it will be carried out by prioritizing: Guarantee Funds, Credit Networks, Credit Facilities and Collateral Reserves. The handling mechanism of the settlement of Exchange transactions in detail is regulated in KPEI Regulation Number II-5 concerning Clearing and Guarantee of Exchange Transaction Settlement of Equity-Type Securities. In addition, KPEI issues several rules relating to settlement of Exchange transactions on equity securities , namely the KPEI II-1 Regulation concerning Clearing and Guarantee of Scripless Exchange Transactions and KPEI Regulation No. II-15 concerning Clearing and Guarantee for Settlement of Unsecured Securities Transactions and Transactions Separated from Equity Type Securities.

The settlement guarantee of Exchange transaction is effort of capital market authorities and SROs to manage the default risk that has potential to arise and harm investors. In addition to guaranteeing the settlement of Exchange transactions by KPEI, OJK has issued POJK Number 49 / POJK.04 / 2016 concerning Investor Protection Funds . Unlike KPEI which functions to guarantee and ensure that the parties carry out obligations and obtain their rights, the capital Funds Protection organized by Indonesia SIPF serves to protect investors from the loss of assets deposited with the Custodian. For this Custodian the Investor assets are Securities and other assets relating to Securities, and / or funds owned by Investors, which are entrusted to Broker-Dealer (PPE) and Custodian Banks. With so, there exist t 2 investor protection mechanisms in the capital market, which guarantees completion of the transaction at the Exchange and protection of investor assets deposited in the PPE and the Custodian Bank.

From the two investor protection mechanisms above, there are several legal issues. First, what is KPEI's position in guaranteeing the exchange transactions settlement, if there is failure due to securities transaction failure that will have implications for capital market activities? This issue is urgent because KPEI is one of the FMIs whose function is to overcome transaction settlement failures that can cause systemic risks. Second, relating to the Investor Protection Fund. Protection Fund Indonesia Management by SIPF become urgent in order to provide optimal protection for investors. Based on a review of the regulatory and legal issues in ensuring the completion of the transaction on the Exchange and the organizer of Investor Fund Protection, the issues to be studied are: 1) How is the position setting of KPEI as financial market infrastructure that perform the function of central counterparty? 2) how is the concept of guarantee fund management and optimal investor protection fund for 
the purpose of guaranteeing the settlement of Exchange transactions and protection of investor assets?

\section{RESEARCH METHODS}

This research uses normative juridical approach, which emphasizes secondary data, with descriptive analytical research specifications. The data used are secondary data in the form of primary, secondary and tertiary legal materials. All data are analyzed using qualitative juridical analysis.

\section{RESULT AND DISCUSSION}

\section{a. The KPEI authority as Central Counterparty in the Guaranteeing the Exchange} Transaction Settlement

KPEI is the only Clearing and Guarantee Institution or Central Counter party in the capital market that has important function, namely as entity that connects the parties in the Exchange transaction. KPEI is domiciled as buyer for each seller and becomes seller to each buyer, thus guaranteeing the performance of open contracts. From legal perspective, the legal relationship between members of the Selling Exchange, KPEI and such Buy Exchange members contains novative elements (debt renewal) which are subjectively active (P originating from 1413 Civil Code). Rather different from subjective novations where there is creditors or debtors replacement as central counterparty, KPEI also replaces both creditors and debtors. Thus, there has been development or expansion of novation meaning used in the guarantee mechanism for settlement of Exchange transactions. In addition to the novation element, in the guarantee mechanism the Exchange transaction settlement is available subrogation or reimbursement of the rights of debtors (members of the Selling Exchange and members of the Buy Exchange) by KPEI based on the provisions of the Law (Article 1400 of the Civil Code) and representatives or powers according to the law (vertegenwoording wettelijke or legal mandatory). The entire civil aspect in the function of KP EI as a Central Counterparty is a capital market contribution to the renewal of Civil Law. ${ }^{8}$

Central counter parties that function well can increase security, efficiency and transparency in the financial system. ${ }^{9}$ With KPEI as central counter party, the capital market guarantees that the parties to the transaction will not face the risk of default or failure to deliver. In carrying out the guarantee function, KPEI is faced with various potential risks. For this reason, KPEI must measure, monitor and manage credit risk, liquidity risk and market risk. Credit risk has the potential to emerge because of the certain Clearing Member's inability to meet obligations to KPEI. This credit risk poses threat to KPEI as Central Counterparty and has systemic risk for the stability of financial markets in general. Increase in systemic risk occurs through concentration of risk in the central counterparty. Errors in central counterparties have the potential to have a strong impact on clearing participants, related central counterparties, and other entities and markets, which have the potential to affect national (or

${ }^{8}$ Lastuti Abubakar, Derivative Transactions in Indonesia - Overview of Laws on Derivative Trade on the Stock Exchange, Books Terrace \& Library, Bandung, 2009. 277.

${ }^{9}$ IMF, 2015: 4 
global) financial stability. Loss of credit or liquidity can quickly spread to markets and other financial institutions. ${ }^{10}$ This credit risk can arise from parties such as Clearing Members, Paying Banks and / or Banks issuing Cash and Cash equivalents, and Stock Loans Counterparties. In addition to credit risk, KPEI must ensure effective measurement, supervision and management of liquidity risk. KPEI manages the adequacy of liquid funding sources in all relevant currencies, both on the same day and between days taking into account certain levels of confidence and with certain scenario stress conditions. This is done to Clearing Members and affiliates, which has the potential to cause very large liquidity needs in extreme market conditions but may occur. KPEI is affected by market risk when assessing the risks for each outstanding position of Clearing Members and their customers. In assessing these risks, KPEI uses the margin method. The risk level arises as result of difference in price at the transaction at the last market price. Margin calculated on each position that has not been settled in each market believes equity, derivatives, bonds and securities lending. Margin value will be deduction for collateral value which is component in calculating trading limits for Clearing Members.

Given the risks that have the potential to arise in carrying out their functions, KPEI is given the authority to regulate risk management. There are 2 KPEI Regulations related to risk management, namely KPEI Regulation No. II-13 concerning Risk Calculation and KPEI Regulation No. II-14 About the Credit Network. In order to carry out the guarantee function of the Exchange transaction settlement and risk control, KPEI has the authority to do the following:

a) Establish transaction limits for each clearing member calculated based on the value of Free Collateral for the entire market and for each market.

b) Calculation of risks for each selling offer or purchase request made by Clearing Member;

c) Calculation of risks for each Exchange transaction conducted by the Clearing Member. Calculation of risks for each sale and/or purchase offer made by Clearing Member is carried out by taking into account the level of transaction risk and Clearing Member who conducts the Exchange transaction. Furthermore, based on the calculation of the risk level, KPEI validates the limits of Clearing Member's transactions and based on validation, KPEI has the authority to approve or reject any selling offer or purchase request made by the Clearing Member before being forwarded to the trading system at the Exchange. Selling offers or buying requests that are forwarded to this Exchange can affect the limits of the transaction of the Clearing Member concerned. Calculation of risks for Exchange transactions conducted by Clearing Members is done by setting margins. Intended by margin here are a number of collateral frozen (blocked collateral) by KPEI for the purpose of guaranteeing the settlement of Exchange transactions and/ or Exchange Transaction settlement. In the event that collateral is insufficient to meet margin requirements, KPEI determines the need for additional collateral that must be fulfilled by the Clearing Member. In addition to risk calculation as a risk management effort in transaction settlement, KPEI requires each Clearing Member to accept the liability responsibilities of the Credit Network in accordance with KPEI Regulation No. II14. The credit network is a Clearing Member both individually and jointly required to cover KPEI obligations relating to the Exchange Transaction Settlement Guarantee. This Credit Network Obligation arises if all financial resources that can be used by KPEI are based on

\footnotetext{
${ }^{10}$ IMF, 2015: 4
} 
POJK No. 26/POJK.04/2014 concerning Guarantee of Exchange Transaction Settlement is not enough to carry out the Guarantee Function of Exchange Transaction Settlement by Clearing Members; and / or failure to fulfill all refunds from the proceeds from the sale of assets of the Clearing Members who have failed the Exchange Transaction Settlement. Furthermore, the provisions regarding the fulfillment of Credit Network obligations and procedures for fulfilling Credit Network obligations are regulated in KPEI Regulation No. II-14 About the Credit Network. In the event that Credit Network members fail in fulfilling the Credit Network, KPEI submits a request to the OJK to take legal action, namely, to "bankrupt" the Credit Network members who fail the Credit Network fulfillment. Furthermore, KPEI will issue Credit Network Obligations to the remaining Credit Network Members to settle the remaining Credit Network Obligations provided that: $20 \%$ of the remaining amount of the Network Liability Credit that is not paid by Credit Network members will be shared equally among the remaining Credit Network members; $80 \%$ of the remaining amount of the Credit Network Obligation will be shared among the remaining Credit Network members proportionally based on the Clearing Value of each Credit Network member for the last 6 months since the issuance of Credit Network Obligations.

Referring to KPEI's authority as central counterparty in guaranteeing the settlement of Exchange transactions, there are 2 strategic issues, namely KPEI's position as Financial Infrastructure in the national financial system, and Guarantee Fund management for the purpose of guaranteeing the settlement of Exchange transactions.

\section{b. KPEI As Central Counterparty and Guarantee Fund Manager}

\section{i. KPEI as Central Counterparty.}

There are 2 main legal issues related to KPEI existence as central counterparty in the Indonesian capital market. First, its position as one of the Infrastructure Market Financials which is obliged to guarantee the completion of Exchange transactions; second, managing Guarantee Funds that will be used to guarantee the settlement of Exchange transactions. These two legal issues cause KPEI to potentially face risks, especially credit risk which can turn into systemic risk and endanger the financial system in general. In addition, the guarantee of Exchange transaction settlement is the spearhead in the protection and legal certainty of the parties transacting at the Exchange, especially selling investors and buying investors. Without the guarantee and legal certainty in investing, it will impact the decline in investor confidence in the Indonesian capital market. Therefore, the regulation of the Indonesian capital market and financial system sector must begin to consider the recommendations of CPSS-IOSCO to consider KPEI as one of the financial market infrastructures in the capital market that is potentially systemic. Law No. 9 of 2016 concerning Prevention and Handling of the Financial System Crisis (PPKSK Law) explicitly only defines Systemic Banks, and has not included financial market infrastructure such as KPEI as a potentially systemic institution. Therefore, it is necessary to study in depth and be careful about the systemic risks that will be faced by KPEI due to failure to settle transactions. Following are some of the CPSS-IOSCO recommendations that have been implemented by KPEI in conducting the guarantee. This recommendation also becomes a measure to minimize risk. ${ }^{11}$

${ }^{11}$ European Central Bank \& Federal reserve Bank of Chicago, The role of Central Counterparties, July, 2007.:20. 
(1) Legal Risk, KPEI must have strong, transparent and enforceable legal framework for every aspect of its activities in all relevant jurisdictions;

(2) Requirements for participation, which require members to have adequate financial resources and strong operational capacity to fulfill emerging obligations. KPEI must have procedures to monitor that these requirements are met;

(3) Measurement and Management of credit exposures by KPEI at least once a day through margin requirements, other risk control mechanisms or combination of both;

(4) KPEI is based on margin requirements to limit its credit exposure. Margin requirements must be based on risk and reviewed regularly.

(5) Financial resources; KPEI must have sufficient financial resources to withstand the failure of participants who have the greatest exposure in extreme but reasonable market conditions.

(6) Default procedure; Standard procedures for handling failures must be clear and transparent and ensure that KPEI can take timely action to avoid liquidity losses and pressures.

(7) Custody and Investment Risk; KPEI must manage and invest guarantee funds in instruments with minimal credit, market and liquidity risks;

(8) KPEI establishes participant requirements and efficient operational.

(9) Governance; governance arrangements for KPEI must be effective, clear and transparent to meet the requirements of public interest and to support the objectives of owners and users.

(10) Transparency; KPEI must provide sufficient information to the participants to accurately identify and evaluate the risks and costs associated with using the service.

(11) Regulation and Supervision; KPEI must comply to transparent and effective regulations and supervision, both nationally and internationally, and cooperate with relevant authorities.

Referring to the above principles, it is worth considering the strengthening of KPEI position as systemic financial market infrastructure.

\section{ii. Guarantee Fund Management}

There are 2 types of Guarantee Funds managed by KPEI, namely Guarantee Funds and Guarantee Fund Reserves. Guarantee Fund is a collection of funds and/or securities administered and managed by KPEI that are used to guarantee the settlement of Exchange transactions, while Collateral Reserves are accumulated funds originating from KPEI's net income in the form of cash or cash equivalents used to conduct guarantor the settlement of Exchange transactions by KPEI.

Guarantee Funds managed by KPEI on September 2018 can be seen in the table below

\begin{tabular}{|lrc|}
\hline Market Type & Value(Rp) & Percentage \\
\hline Equity & $2,763,118,284,212,00$ & $64,06 \%$ \\
\hline Derivative-Future Contract & $597,604,567,00$ & $0,01 \%$ \\
\hline Debt Securities & $1,087,103,00$ & $0,00 \%$ \\
\hline $\begin{array}{l}\text { Results of Equity Guarantee Fund Management, } \\
\text { KBIE, Bonds }\end{array}$ & $1,549,941,548,582,61$ & $35,93 \%$ \\
\hline Total & $4,313,658,524,464,61$ & $100 \%$
\end{tabular}




\section{Source: PT KPEI}

The Guaranteed Reserve Position on August 2018 is Rp. 148,569,268,411.00

Based on POJK No. 26/POJK.04/2014, the use of Guarantee Funds can only be used in the framework of guaranteeing the settlement of Exchange transactions. Guarantee funds can be pledged to obtain bank credit for the purpose of guaranteeing the Exchange transactions settlement. Guarantee Funds used to complete the Exchange transaction must be repaid by the Clearing Member who does not complete the Exchange (subrogation) transaction. It can be said that the guarantee by KPEI uses the concept of underwriting (borgtocht) stipulated in Article 1820 of the Civil Code. The difference is that the guarantee is carried out by KPEI in the form of a Limited Liability Company (PT) or a corporation with special requirements. Thus, the existence of KPEI has helped develop national guarantee law. ${ }^{12}$

In addition, Article 13 POJK No. 26/POJK.04/2014 stipulates that the guarantee fund managed by KPEI not belong to particular party and not distributed to anyone for any purpose except for the purpose of guaranteeing the settlement of Exchange transactions and guarantees to obtain bank loans are only intended to guarantee settlement Exchange transaction. KPEI can invest and manage the Guarantee Fund by paying attention to the principle of prudence. Article 16 POJK No. 26/POJK.04/2014 limiting guarantee funds can only be invested in bank deposits and/or Government Securities. In addition, the composition and limits of the Guarantee Fund Investment value are in accordance with the stipulation of the Credit Policy and Risk Control Committee. Government securities as investment instruments can be guaranteed in securities sale transactions with promises of repurchase agreements and or securities lending and borrowing transactions with the Government and Bank Indonesia.

In managing the Guarantee Fund, KPEI must fulfill the following conditions: 1) separate the storage, recording and bookkeeping between KPEI assets and Guarantee Fund assets; provide safe place for Guarantee Fund assets; 3) Guarantee Funds invested in bank deposits must be placed in banks approved by the Credit Policy and Risk Control Committee; 4) Guarantee funds invested in Government Securities must be deposited in the Securities Account at the Custodian approved by the Credit Policy and Risk Control Committee. Guarantee Fund investment results must be added to the Guarantee Fund after deducting fees for investment management services by KPEI. When viewed from the data in 2018, the results of the management of the Guarantee fund amounted to Rp. 1,440,882,194,879.94 (36\% of the Guarantee Fund) while as of September 2018 was Rp. 1,549,941,548,582.61 (35.93\% of the Guarantee Fund) . Based on these data, the management of the Guarantee Fund has increased but has not been optimal. This is because the Guarantee Fund regulation provides sufficiently stringent signs in the management of the Guarantee. Guarantee Fund management must be carried out carefully because the Fund serves to guarantee the settlement of transactions so as not to create risks of failure that can have systemic consequences. On the other hand, the Guarantee Fund must be managed optimally to strengthen KPEI financial resources so that it can guarantee the Exchange Transaction Settlement guarantee.

\section{iii. Optimization of Capital Protection Funds}

Besides KPEI as institution that guarantees the Exchange transactions settlement, investor legal protection is carried out through the Investor Protection Fund held by the

${ }^{12}$ Lastuti Abubakar, Juridical Study of Development of Institutions and Objects of Guarantee (Ideas for renewal of National Guaranteed Law), Centralized Legal Bulletin, Vol. 12, No. 1, January-June 2015. 
Indonesia Securities Investor Protection Fund (SIPF) based on PJOK No. 49/POJK/04/2016 concerning Investor Protection Funds. Investor Protection Fund is funds collection formed to protect investors from loss of assets of investors. Investor protection is needed to provide sense of security and increase the investors trust to invest in the Indonesian capital market. This becomes urgent, because the capital market has important role in driving national economy. The Investor Protection Fund is international best practice, which is of concern to the world capital market. This can be seen from several recommendations from world bodies such as the Recommendations 2000 International Securities Services Association (ISSA) which expressly states the protection of investors from various risks in the capital market such as settlement risk, legal risk, bankruptcy risk. In some countries like the United States and some European countries generally have implemented schemes or policies in the protection of investors in the capital market. In the United State of America since 1970 known the Securities Investor Protection Corporation (SIPC) which guarantees claims submitted by investors from securities companies that are members of SIPC. In Australia there is the Securities Exchange Guarantee Corporation (SEGC) which has managed the National Guarantee Fund (NGF) since 1987 where the guarantee scheme is not only the risk of bankruptcy of Securities Companies, but other risks faced by investors such as unauthorized transfers, fulfillment of transaction settlement obligations both equity and debt instruments and derivative transactions in Australian Stock Exchange (ASX). In Malaysia there is KLSE Compensation Fund that protects investors from securities company bankruptcies, deficits and/ or fraudulent misuse either by directors, employees or representatives of Securities Companies (Bapepam-LK, 2007: 2). In its development IOSCO has incorporated investor protection into the principles of capital market regulation, one of which is investor protection. Investors in the capital market are particularly vulnerable to violations committed by intermediaries and other parties, however the capacity of investors to take action is very limited. The complex character of capital markets requires strong law enforcement. Investors must have access to neutral mechanisms (such as courts or other dispute resolution mechanisms) or ways of compensation and compensation for inappropriate behavior. Effective supervision and enforcement depends on close cooperation between regulators at the domestic and international level (IOSCO, 2003: 5). Thus, the formation of Investor Protection Fund is the implementation of investor protection in the agreed by IOSCO member countries, including the Financial Services Authority.

When viewed from its function, both KPEI and SIPF have the function of providing legal guarantees and protections for investors who transact in the capital market. The difference is that KPEI guarantees that the parties transacting at the Exchange, namely the buyer and seller, obtain what is their right. KPEI ensures that there are no defaults or failures in transactions at the Exchange. Indonesia SIPF provides protection for investors assets held in Custodians, which are lost not because of investors mistakes. Indonesia SIPF position in the mechanism of the Investor Fund's protection is similar to KPEI position in the transaction settlement guarantee mechanism. Indonesia SIPF will me replace losses on lost shareholders 'assets and replace investors position against the Custodian because of subrogation. Indonesia SIPF guarantees compensation to investors who are customers of Custodian Banks and Brokerage Brokers who are members of the Indonesian SIPF. Currently there are 19 Custodian Banks and 105 Intermediary Securities traders who are members of SIPF Indonesia who have an obligation with priority to protect Indonesian investors' investments. Indonesia SIPF immediately handles the claims of investors who lost their assets after an official statement 
from the FSA regarding the condition of investor investment. B based on Indonesian SIPF data, the Investor Protection Fund as of August 2018 was Rp. 158.54 Trillion, while the assets of investors amounted to Rp.4,268.64 Trillion. This Investor Protection Fund comes from initial funding contributions from SROs (Securities Exchanges, Clearing and Guarantee Institutions, and Deposit and Settlement Institutions), membership fees, replacement funds as implementation of certification rights, investment returns from Investor Protection Funds and other sources determined by OJK.

Members of the Investor Protection Fund as much as 124 and accounts of investors sub-accounts amounted to 915,339 accounts. Looking at the comparison between Investor Protection Funds and investor assets, Indonesia SIPF is required to optimize Investors Funds investment investments in order to provide maximum protection.

Not all investors are protected by their assets. Article 21 POJK concerning the Investor Protection Fund stipulates that "Investors whose assets receive protection from the Investor Protection Fund are investors who meet the following requirements:"

1) Leave the assets and have Securities account with the Custodian;

2) Sub Securities Account opened at the Depository and Settlement Agency (Indonesian Central Securities Depository) by the Custodian; and

3) Have single number of investor identity from the Depository and Settlement Institution (KSEI)

Payment of compensation to investors using SIPF is carried out if the following conditions are met:

1) The Financial Services Authority has issued written statement that there is loss of investor assets;

2) Custodians do not have the ability to recover lost investor assets;

3) For Custodian in the form of Broker Dealer that administers securities, it is stated that it cannot continue its business activities and is considered to have been revoked by OJK; or for Custodian Bank unable to continue its business activities as Custodian Bank, and it is considered that the approval of the Commercial Bank as Custodian is revoked by the OJK.

Payment of compensation is given in the form of funds in the amount of investor assets value lost and/ or in accordance with the highest limit for each investor and each Custodian. Indonesia SIPF has published that the amount of compensation for assets of investors is Rp. 100 million per investor and Rp.50 billion per custodian. The limitation on the amount of compensation does not erase the rights of investors to claim the remaining compensation.

Similar to the Guarantee Fund managed by KPEI, Investor Protection Funds do not belong to a particular party and are not used for any purpose except for the intended purpose. Indonesia SIPF can invest in Investor Protection Funds in Government Securities and / or Deposits at state banks. Slightly different from the Guarantee Fund, investor protection funds cannot be loaned or guaranteed. Indonesia SIPF has the right to receive compensation for management services for Investors Protection Fund investments of $10 \%$ of the net income from investment returns.

\section{Trust: Concept of Collateral Management and Investor Protection Fund}

Either KPEI or Indonesia SIPF are faced with risks, namely the potential loss experienced by investors in the event of failure to settle Exchange transactions or loss of investor assets due to the risk of insolvency or loss of assets due to misuse by securities 
company management. To carry out its functions optimally, KPEI and SIPF were given the authority to manage the Fund, namely the Guarantee Fund by KPEI and the Investor Protection Fund by Indonesia SIPF. The concept of fund management based on regulations reveals the prudential principle considering that the funds managed are not KPEI or Indonesian SIPF funds. Who does this fund even have? also and managed for the purposes set by the POJK Guarantee Fund and the POJK Investor Protection Fund. The concept of fund management based on two POJK is investment with fixed and relatively safe income, namely Government Securities and deposits. Especially for KPEI, transaction failures have the potential to cause systemic risks that can have negative impact on the financial system, so efforts are needed to increase the Guarantee Fund to secure the failure of transaction settlement. Indonesia SIPF is also required to be able to increase the Investor Protection Fund in order to provide optimal protection to all investors. therefore, fund management should be optimized using the Trust concept (safekeeping with management), where KPEI and Indonesia SIPF as Trustee who will manage all funds for the interests of the Beneficiary. In this context the Beneficiary is the capital market industry itself and investors. In positive law of Indonesia, the trust concept was introduced in POJK No. 25/POJK.03/2016 concerning Amendments to POJK No. 27/POJK.03/2015 concerning Bank Business Activities in the Form of Management with Trusts. This POJK Trust is only intended for Banks as Trustees to manage funds deposited by Settlor (asset owners) for the benefit of Beneficiary. Trust activities by banks are adaptation of the trust concept originating from the common law system. The trust concept essence is dual ownership of an asset, namely Trustee as legal owner and Beneficiary as legal owner. POJK Trust conducts trust adaptations by using agreements as the basis of legal relations between Trustee and Settlor. ${ }^{13}$ As agreement that developed in banking practice, the trust concept can be used as effort to provide flexibility in the management of Guarantee Funds and Investor Protection Funds by continuing to prioritize the prudential principles. In the future, civil law reforms will still be needed that will accommodate the trust concept, especially Book II of the Civil Code that does not recognize dual ownership. The use of trust concept in the management of Guarantee Funds and Investor Protection Funds can refer to the PJOK Trust.

\section{CONCLUSION}

Based on the analysis and discussion that has been described, it can be concluded as follows:

Exchange transaction guarantee and Investor protection Fund is effort to boost the confidence of investors to invest in Indonesia capital market. KPEI is infrastructure financial market that functions to ensure that there is no failure of transaction settlement that can risk systemic and disrupt the national financial system. Therefore, KPEI can be considered as systemic financial service institution that requires strong regulatory support. In addition to KPEI, Investor Protection Funds are means of providing protection to investors for assets lost due to the securities company insolvency or Custodian Bank and tan is inappropriate by the management of the Security Company or the Custodian Bank.

\footnotetext{
13 Tri Handayani \& Lastuti Abubakar, Implications of Custodian Business Activities with Management (Trust) in Banking Activities towards Renewal of Indonesian Civil Law, Litigation Journal, Vol. 15, No. 2,2014 : 2450
} 
Guarantee Funds and Investor Protection Funds can be managed by KPEI and Indonesia SIPF by investing in Government Securities and deposits (fixed income). Based on data from KPEI and Indonesia SIPF, guarantee funds and Investor Protection Funds have not been able to cover all the guarantee requirements for transaction settlement and investor asset protection. Guarantee Funds and Investor Protection Funds do not belong to anyone and not to anything except those determined by POJK Guarantee Fund and POJK Investor Protection Fund. To optimize these funds, the trust concept can be used to provide more optimal Exchange Transaction Settlement Guarantee and protection for investors. KPEI and Indonesia SIPF act as Trustee (legal owner) which will manage the fund for the benefit of beneficiary (beneficial owner), namely capital market industry, especially investors. The management using the trust concept still prioritizes the principle of prudence, the principles of the agreement and adopts the principle or maxim trust which is regulated in the common law system.

\section{REFERENCES}

\section{Book}

Bapepam-LK, Questionnaire Study of the Establishment of Investor Protection Fund, Ministry of Finance-RI, 2007.

Committee on Payment and Settlement Systems \& Technical Committee of the International Organization of Securities Commission, Principles for Financial Market Infrastructure, BIS \& IOSCO, 2012.

European Central Bank \& Federal reserve Bank of Chicago, The role of Central Counterparties, July, 2007.

Froukelien Wendt, Central Counterparties: Addressing Their Too Important to Fail Nature, IMF Working Paper - Monetary and Capital Markets, International Monetary Fund, 2015.

International Organization of Securities Commissions, Objectives and Principles of Securities regulation, May, 2003.

KPEI, IDX, KSEI, Press Release http://www.ksei.co.id/ files/uploads/press_releases/ press_file/id-id/ 150_siklus_penyesai_bursa _t_2_20180720152935.pdf

KPEI \& KSEI, http://www.ksei.co.id/ Announcement/files/ 77891_kpei_0701_dir_0717 dan_ksei_5510_dir_0717_201707100802.pdf).

Kontan.co.id, https://investasi.kontan.co.id/ news/ojk-sedang-menangani-46-kasus-pasarmodal)

Financial Services Authority, 2018, Capital Market: Weekly Statistics - September 2018, https://www.ojk.go.id/ id/kanal/pasar-modal/data-dan-statistik/statistik-pasarmodal/Documents/Statistik \% 20September\% 20Mgg\% 20 to 2\% 202018.pdf

Lastuti Abubakar, Derivative Transactions in Indonesia - Overview of Laws on Derivative Trade on the Stock Exchange, Books Terrace \& Library, Bandung, 2009.

Lastuti Abubakar \& Tri Handayani, Readiness of Legal Infrastructure in the Issuance of Sukuk (Sharia Securities) as an Instrument of Financing and Investment to Encourage the Growth of Indonesian Sharia Capital Markets, Jurisprudence Journal, Vol.7, No.1, Juni2017, http: //journals.ums.ac.id/ index.php / jurisprudence / article / view / 4348/2776 
Trunjoyo Law Review Vol.1 No.1 2019

La stuti Abubakar \& Tri Handayani, Development of Regulations on Scripless Stock Guarantees as Objects of Transactions in the Capital Market, Justitia Legal Journal, Vol. 2, No. 1, 2018, http://journal.um-surabaya.ac.id/ index.php/Justitia/article/view/1715/1377.

Lastuti Abubakar, Juridical Study of Development of Institutions and Objects of Guarantee (Ideas for renewal of National Guaranteed Law), Centralized Legal Bulletin, Vol. 12, No. 1, January-June 2015.

KPEI, Guarantee Fund Position of September 2018, http://www.kpei.co.id/ Media/Default/Statistic/_ Dana\%20Jaminan/2018/

Posisi\%20Dana\%20Jaminan\%20September\%202018.pdf

Tri Handayani \& Lastuti Abubakar, Implications of Custodian Business Activities with Management (Trust) in Banking Activities towards Renewal of Indonesian Civil Law, Litigation Journal, Vol. 15, No. 2,2014. 